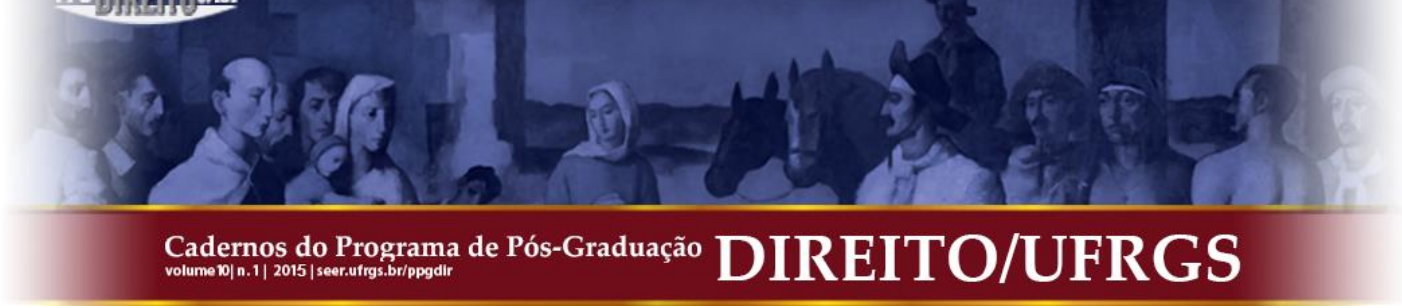

\title{
AS EMPRESAS ESTATAIS E O COMPROMISSO DE AJUSTAMENTO DE CONDUTA
}

\author{
STATE-OWNED COMPANIES AND THE CONDUCT ADJUSTMENT AGREEMENT
}

\author{
Wilson José Vinci Júnior*
}

\begin{abstract}
RESUMO: O presente artigo versa sobre a possibilidade das empresas estatais firmarem compromisso de ajustamento de conduta. O motivo do questionamento reside no texto da Lei Federal no 7.347/85, que em seu artigo $5^{\circ}$, parágrafo $6^{\circ}$ estabelece que os "órgãos públicos" legitimados para ajuizar ações civis públicas poderão tomar dos interessados compromisso de ajustamento de conduta, sendo cediço que, tecnicamente, as empresas estatais não são consideradas "órgãos públicos". A controvérsia é acentuada pelo fato de que, embora submetidas ao regime jurídico de direito privado, as empresas estatais estão incluídas na estrutura da Administração Indireta do Estado. Ao final, mediante uma análise jurídica, será apresentada conclusão no sentido da possibilidade das empresas estatais celebrarem o compromisso de ajustamento de conduta.
\end{abstract}

PALAVRAS-CHAVE: Empresas Estatais. Termo de Ajustamento de Conduta. Administração Indireta do Estado.
ABSTRACT: The present article deals with the possibility of stateowned companies to enter into a conduct adjustment agreement. The doubt lies on the text of the Brazilian Federal Statute No. 7347/85, which in its article 5, paragraph 6, establishes that the "public bodies" entitled to be plaintiffs in Brazilian public civil actions (ações civis públicas) are able to obtain conduct adjustment agreements from interested parties, being of general knowledge that, technically, state-owned companies are not considered "public bodies". The controversy is highlighted by the fact that, although submitted to a private law legal regime, state-owned companies are included in the indirect state administration structure. At the end, through a legal analysis, it will be presented a conclusion towards the possibility of state-owned companies to enter into a conduct adjustment agreement.

KEYWORDS: State-owned Companies. Conduct Adjustment Agreement. Indirect State Administration.

SUMÁRIO: Introdução. 1. Evolução legislativa e base constitucional da tutela dos interesses difusos e coletivos no ordenamento jurídico brasileiro. 2. Breve introdução acerca do compromisso de ajustamento de conduta. 2.1. Conceito e natureza jurídica. 2.2. Objeto. 2.3 Requisitos e procedimento. 2.4. Efeitos da celebração do compromisso de ajustamento de conduta. 3. A administração indireta do Estado/ Das empresas públicas e sociedades de economia mista. 3.1. O fenômeno da autarquização das empresas estatais prestadoras de serviços públicos. 3.2. As empresas públicas e as sociedades de economia mista como legitimadas para a celebração de compromisso de ajustamento de conduta. Conclusão. Referências.

\section{INTRODUÇÃO}

As últimas décadas foram de grandes transformações na área jurídica, mediante o aperfeiçoamento de determinadas matérias, bem como o surgimento de novos ramos do Direito.

É cediço que o Direito é uma ciência una, sendo que a sua divisão ocorre principalmente para facilitar o estudo (autonomia didática) e sua aplicação prática mediante leis específicas (autonomia legislativa). Nesse diapasão, um ramo do Direito é autônomo quando possui métodos, princípios, institutos e normas próprias.

Dentre as novidades das últimas décadas podem ser citadas o biodireito, o direito digital, o aperfeiçoamento do direito comercial para direito de empresa e a evolução dos direitos difusos, que, no Brasil, se expandiram com mais afinco a partir da década de 1980.

\footnotetext{
* Mestrando em Direito Administrativo pela Pontifícia Universidade Católica de São Paulo. Procurador Federal. Cadernos do Programa de Pós-Graduação em Direito PPGDir./UFRGS | Edição Digital | Porto Alegre | Volume X | Número 1 | 2015 | P.211-235
} 


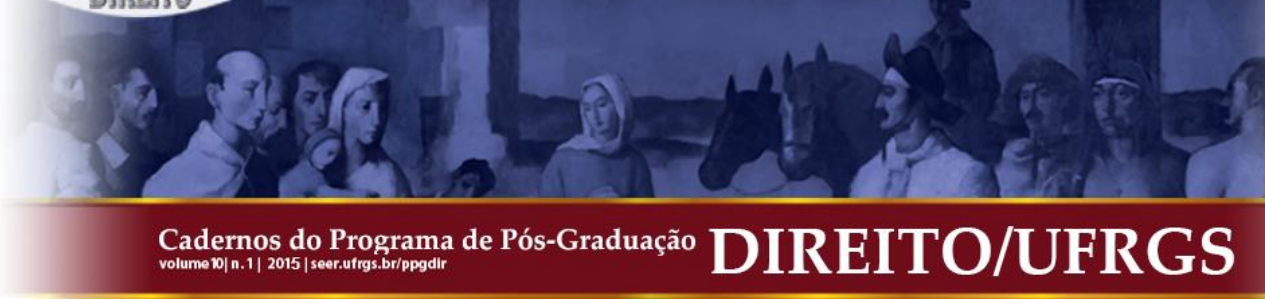

Assim, a autonomia dos direitos difusos ocorreu concomitantemente com a modificação social oriunda da crescente urbanização da população, dos meios de produção em massa, da economia cada vez mais complexa, enfim, de uma sociedade cada vez mais plural e com interesses variados.

Por ser um ramo da ciência jurídica relativamente novo, em franca ascensão, muitas dúvidas surgem em relação à aplicação dos direitos difusos, seja em seu aspecto material ou processual. Nesse sentido, convém consignar que, até os dias atuais, o Brasil ainda não possui nenhum Código de Processo Civil Coletivo, apesar da tramitação de alguns projetos de lei sobre a matéria ${ }^{1}$.

Desta feita, o presente trabalho pretende discutir uma dessas dúvidas, qual seja, saber se as empresas públicas e as sociedades de economia mista podem celebrar compromisso de ajustamento de conduta.

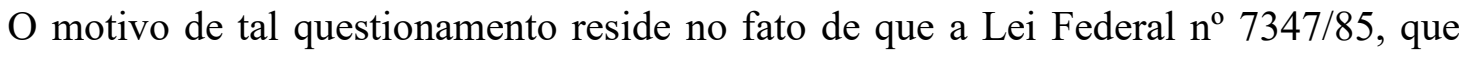
regulamenta o procedimento da ação civil pública, prevê em seu artigo $5^{\circ}$, inciso IV, a legitimidade das empresas públicas e das sociedades de economia mista para ingressarem com ação civil pública. No mesmo preceito legal, em seu parágrafo $6^{\circ}$, a mencionada lei estabelece que os órgãos públicos legitimados poderão tomar dos interessados compromisso de ajustamento de sua conduta às exigências legais, mediante cominações, que terá eficácia de título executivo extrajudicial.

É de se ver que o alcance da expressão “órgãos públicos” comporta divergência, afinal, ao mesmo tempo em que as empresas públicas e as sociedades de economia mista são “entidades estatais", pois criadas ou autorizadas por lei, elas possuem a natureza jurídica de pessoas jurídicas de direito privado, submetendo-se ao regime jurídico de direito privado, com algumas derrogações do direito público. Logo, tecnicamente, elas não são consideradas “órgãos públicos".

Desta maneira, o fato de tais entidades se submeterem ao regime jurídico de direito privado, ao mesmo tempo em que são obrigadas a observarem vários dispositivos de direito público, faz com que nasça a divergência se as empresas públicas e as sociedades de economia mista podem ou não celebrar compromisso de ajustamento de conduta.

Tal polêmica é acentuada por recente posicionamento jurisprudencial do Supremo Tribunal Federal-STF que parece aproximar cada vez mais as empresas públicas e sociedades

${ }^{1}$ A título de exemplo, vide projeto de lei no 5139/2009.

Cadernos do Programa de Pós-Graduação em Direito PPGDir./UFRGS | Edição Digital | Porto Alegre | Volume X | Número 1 | 2015 | P.211-235 


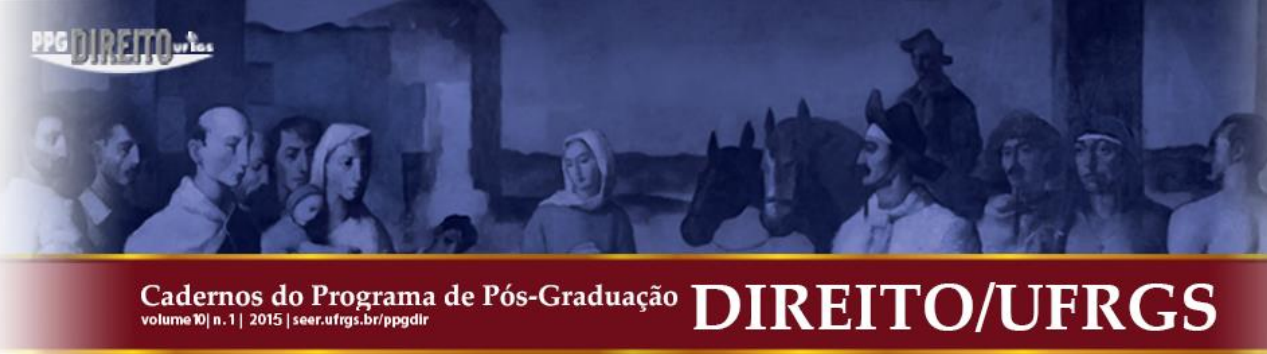

Aqui, cabe esclarecer dois pontos: em primeiro lugar, obviamente, há outros diplomas legais que tratam da proteção dos interesses transindividuais (buscou-se apenas citar algumas leis que possibilitassem a compreensão da evolução legislativa acerca da matéria); em segundo lugar, é mister ressaltar que a Lei de Ação Civil Pública (Lei no 7347/85) e o Código de Defesa do Consumidor (Lei $\mathrm{n}^{\mathrm{o}}$ 8078/90) formam o expoente da proteção dos interesses transindividuais, o que a doutrina chama de "microssistema de tutela coletiva", uma vez que estes dois diplomas legais possuem normas recíprocas e complementares de atuação do direito processual coletivo, constituindo o instrumento por meio do qual a pretensão coletiva será deduzida em juízo.

No âmbito constitucional, é inegável a contribuição que a Carta Magna de 1988 conferiu de forma pioneira no constitucionalismo brasileiro aos interesses transindividuais.

Isto porque,

além de prever a diretriz da defesa do consumidor - parte vulnerável na relação com o fornecedor - pelo Estado, concretizando o princípio da isonomia (art. $5^{\circ}$, XXXII; art. 170, V; art. 48 das Disposições Transitórias), a Constituição instituiu o mandado de segurança coletivo (art. $5^{\circ}$, LXX); possibilitou aos sindicatos e associações defender em juízo interesses da respectiva coletividade (art. $5^{\circ}$, LXXIII); aumentou o número de legitimados para a propositura de ação direta de inconstitucionalidade; e, finalmente, fez referência expressa à ação civil pública, para a proteção do 'patrimônio público e social, do meio ambiente e de outros interesses difusos e coletivos', cuja promoção é função institucional do Ministério Público, sem exclusão de outros entes (art. 129, III e par. $1^{\circ}$ ). (BENJAMIM, 2009, p. 382).

É importante salientar que, tanto com a Constituição Federal quanto com o Código de Defesa do Consumidor, houve a ampliação do objeto de incidência da ação coletiva. Assim, nos dias atuais, praticamente qualquer pretensão pode ser veiculada por meio da ação coletiva, desde que se caracterize tutela de interesse difuso, coletivo ou individual homogêneo ${ }^{3}$. Também qualquer pedido pode ser veiculado por essas ações, seja pedido de natureza constitutiva, declaratória, mandamental ou executiva, conforme dispõe o artigo 83 do CDC.

Por fim, ressalte-se que a evolução legislativa, pela sua própria natureza, é tarefa contínua, de modo que, atualmente, é muito comentada a necessidade de um Código de

\footnotetext{
${ }^{3}$ Não se desconhece que o artigo $1^{\circ}$, parágrafo único da Lei Federal no 7347/85 estabelece que “não será cabível ação civil pública para veicular pretensões que envolvam tributos, contribuições previdenciárias, o Fundo de Garantia do Tempo de Serviço - FGTS ou outros fundos de natureza institucional cujos beneficiários podem ser individualmente determinados." Todavia, além desse preceito legal ser exceção que confirma a regra exposta, cabe ressaltar que uma grande parte da doutrina o aponta como inconstitucional, seja porque inserido pela medida provisória $n^{\circ}$ 2180-35, de 2001, sem a observância dos requisitos da relevância e da urgência (art. 62, CF), seja porque não há razão jurídica plausível para se limitar o âmbito de cabimento da ação civil pública.
} 


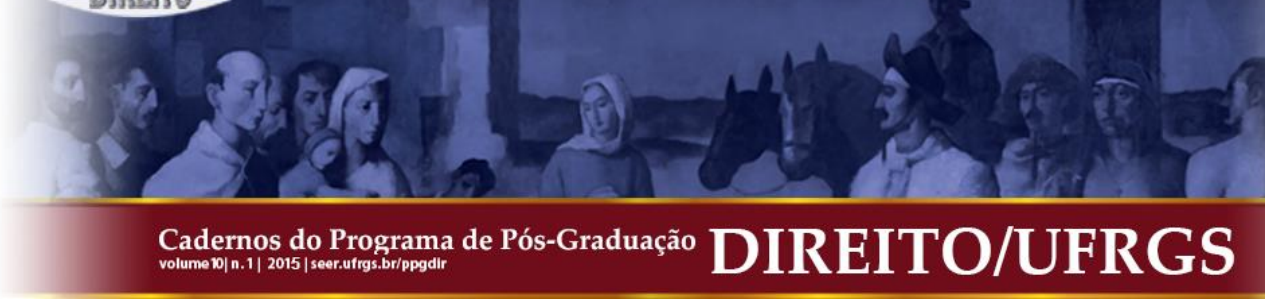

Processo Civil Coletivo, ainda em fase de projeto de lei em trâmite junto ao Congresso Nacional.

\section{BREVE INTRODUÇÃO ACERCA DO COMPROMISSO DE AJUSTAMENTO DE CONDUTA}

Hodiernamente, com o fenômeno da excessiva "judicialização da vida", é indubitável que o Poder Judiciário se encontra sobrecarregado. As causas deste congestionamento não são propriamente o escopo do presente trabalho, que mais se interessa com a consequência da morosidade judicial.

Nesse cenário, qualquer forma de solução de controvérsia extrajudicial surge como tentativa de minimizar o problema do excessivo número de lides a cargo do Poder Judiciário, ao mesmo tempo em que busca atingir a pacificação social, objetivo este dito por muitos como o escopo da ciência jurídica.

Destarte, por meio do compromisso de ajustamento de conduta, é negociado um modo de alinhar a conduta do causador de um dano aos preceitos legais que disciplinam determinada matéria, de maneira mais econômica, ágil e eficaz em relação ao processo judicial. Assim, observa-se que a participação do responsável pelo suposto ato ilícito na solução do problema, tende a conferir maior legitimidade ao compromisso de ajustamento de conduta, se comparado a uma decisão judicial prolatada por um magistrado (negociação da solução versus imposição da solução). Isso faz com que o compromisso de ajustamento de conduta seja erigido a um relevante meio de proteção dos direitos transindividuais.

A previsão legal para a lavratura do compromisso de ajustamento de conduta está insculpida no art $5^{\circ}$, parágrafo $6^{\circ}$ da Lei Federal $n^{\circ} 7347 / 85$ (LACP), o qual possui a seguinte redação: “os órgãos públicos legitimados poderão tomar dos interessados compromisso de ajustamento de conduta às exigências legais, mediante cominações, que terá eficácia de título executivo extrajudicial."

Há outros diplomas legais que preveem expressamente a possibilidade de se firmar o compromisso de ajustamento de conduta: Estatuto da Criança e do Adolescente (Lei Federal n ${ }^{\circ}$ 8069/90 em seu art. 211); Lei de Repressão a Crimes Ambientais (Lei Federal nº 9605/98 em seu art. 79-A); Lei da Defesa da Concorrência (Lei Federal nº 12.529/11 em seu art. 85), além da Resolução nº 23/2007 do Conselho Nacional do Ministério Público (art. 14). 


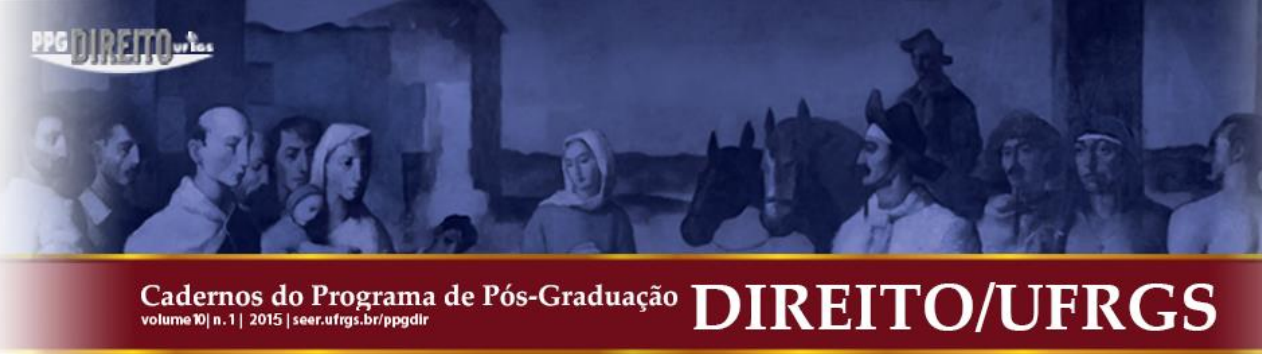

É cediço que os legitimados que atuam na defesa dos direitos transindividuais não são os titulares do direito material objeto do litígio. Desta maneira, tais legitimados não possuem a disponibilidade do conteúdo material da lide, afinal, não podem dispor daquilo que não lhes pertencem. Assim, à primeira vista, os legitimados não poderiam transigir sobre interesses dos quais não são titulares.

Ocorre que, ao se discorrer sobre o compromisso de ajustamento de conduta, estar-se-á a falar, como o próprio nome designa, sobre o ajuste, às exigências legais, do modo de agir do suposto causador do dano ao interesse transindividual.

Desta maneira, a "transação" em relação ao agir do causador do dano não tem o condão de significar transação sobre o direito material pertencente à coletividade, seja esta coletividade determinada ou não.

\subsection{Conceito e Natureza Jurídica}

Inicialmente, é importante conceituar o compromisso de ajustamento de conduta. Para Marcelo Sciorilli (2012, p. 810),

[..] por compromisso de ajustamento de conduta entende-se, então, o negócio jurídico celebrado perante um órgão público para a adequação de conduta de pessoas físicas ou jurídicas, públicas ou privadas, às exigências legais, mediante cominações necessárias à prevenção, cessação ou reparação do dano a interesses supraindividuais.

O compromisso de ajustamento de conduta pode ser celebrado no bojo de um processo judicial (necessitando, pois, de homologação do juiz) ou extraprocessualmente.

Em relação à natureza jurídica, Marcelo Sciorilli (2012, p. 810) sintetiza bem a divergência:

Das mais variadas são as opiniões sobre a natureza jurídica desse compromisso: transação, transação atípica, acordo em sentido estrito, ato administrativo negocial, dentre outras. No Superior Tribunal de Justiça, tem prevalecido a orientação de que o compromisso de ajustamento de conduta constitui uma transação.

Na lição de Hugo Nigro Mazzilli (2005, p. 359),

[...] é, pois, o compromisso de ajustamento de conduta um ato administrativo negocial por meio do qual só o causador do dano se compromete; o órgão público que o toma, a nada se compromete, exceto, implicitamente, a não propor ação de conhecimento para pedir aquilo que já está reconhecido no título. 


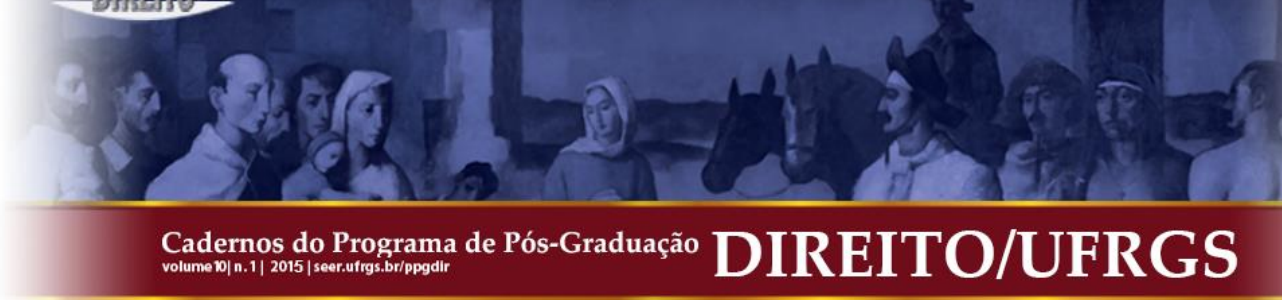

Parece, portanto, que a posição majoritária entende que o compromisso de ajustamento de conduta possui natureza jurídica de transação. Todavia, este entendimento é criticado pois o vocábulo "transação" está intimamente ligado à ideia de direito patrimonial de caráter privado (art. 841 do Código Civil). Obviamente, há pontos em comum entre a transação do direito privado e o compromisso de ajustamento de conduta, tais como o consenso na sua celebração. Todavia, não se pode afirmar que os interesses transindividuais ostentam caráter privado e, ainda por cima, patrimonial.

Assim, independentemente da corrente doutrinária que se adote em relação à natureza jurídica do CAC (compromisso de ajustamento de conduta), fato é que, se celebrado extraprocessualmente, terá eficácia jurídica de título executivo extrajudicial ${ }^{4}$ e, quando celebrado no bojo de um processo com a homologação do juiz, terá eficácia jurídica de título executivo judicial. Esta diferenciação guarda relevância prática em relação às matérias de defesa que futuramente poderão ser alegadas por aquele que descumprir o CAC.

Vale ressaltar o caráter de facultatividade na celebração do CAC, seja pelo órgão público legitimado a firmá-lo ou pelo causador do dano interessado em ajustar a sua conduta aos preceitos legais.

Por fim, frise-se que

[...] o compromisso é formalizado, em geral, por meio de um termo que contém as obrigações assumidas, prazos para cumprimento e respectivas cominações. Esse termo, que constitui o instrumento de formalização da avença, é comumente conhecido por TAC (Termo de Ajustamento de Conduta). (NUNES JÚNIOR, 2012, p. 809).

Termo, portanto, é o instrumento que formaliza o compromisso de ajustamento de conduta.

\subsection{Objeto}

De uma maneira geral, podem ser objeto do compromisso de ajustamento de conduta todo e qualquer direito transindividual que possa ser tutelado por meio de ação civil pública.

\footnotetext{
${ }^{4}$ Conforme artigo $5^{\circ}$, parágrafo $6^{\circ}$, da Lei Federal no 7347/85 (LACP).

Cadernos do Programa de Pós-Graduação em Direito PPGDir./UFRGS | Edição Digital | Porto Alegre | Volume X | Número 1 | 2015 | P.211-235
} 
Em outras palavras, todos os direitos difusos, coletivos e individuais homogêneos que digam respeito, por exemplo, aos consumidores, ao meio ambiente, à saúde pública, às crianças e aos adolescentes, podem ser objeto de celebração do CAC.

Todavia, há uma exceção: o artigo 17, parágrafo $1^{\circ}$ da Lei Federal nº 8429/92 (Lei de Improbidade Administrativa-LIA) veda expressamente a transação, acordo ou a conciliação em matéria de improbidade administrativa. Ocorre que tal exceção atualmente é compreendida como a vedação à qualquer espécie de transação em relação às sanções previstas no art. 12 da LIA, como perda de bens acrescidos ilicitamente, suspensão dos direitos políticos, perda da função pública, multa civil etc. Porém, tem-se admitido a transação para fins de reparação integral do dano causado ao erário. Assim, poderia haver uma maneira de se conciliar a forma como será reparado o dano causado ao património público, sem que se possa transigir em relação às penalidades a que o causador do dano estará sujeito ${ }^{5}$.

O CAC pode veicular qualquer tipo de obrigação jurídica, como fazer, não fazer, pagar certa quantia, tudo visando à efetiva prevenção, cessação ou reparação do dano.

Convém novamente explicitar que não é admitida a disponibilidade do direito material objeto da controvérsia, afinal, os legitimados para a celebração do CAC não são titulares dos bens jurídicos em questão. Vale dizer: não há a possibilidade de renúncia ou limitação de responsabilidade no CAC.

\subsection{Requisitos e procedimento}

Pode-se afirmar que o compromisso de ajustamento de conduta pertence ao gênero negócio jurídico e, como tal, para a sua validade requer (i) agente capaz, (ii) objeto lícito, possível, determinado ou determinável (iii) forma prescrita ou não defesa em lei (art. 104 do Código Civil).

Além disso, outros requisitos são necessários, muito bem sintetizados por Marcelo Sciorilli (2012, p. 814):

\footnotetext{
${ }^{5}$ Por todos, convém citar a posição de Emerson Garcia e Rogério Pacheco Alves (2008, p. 595), para quem “(...) o que realmente o legislador desejou foi proibir a celebração de termos de ajustamento de conduta, em matéria de improbidade, de modo a que se afastasse o ajuizamento da ação em busca de aplicação das sanções previstas no art. 12. Não vedou o legislador, no entanto, que se acordasse quanto às condições, ao prazo e ao modo de reparação do dano causado ao erário ou mesmo quanto à perda da vantagem ilicitamente obtida pelo agente (arts. $9^{\circ}$ e 18 da Lei 8.429/92), inclinando-se para tal solução a melhor orientação doutrinária." 


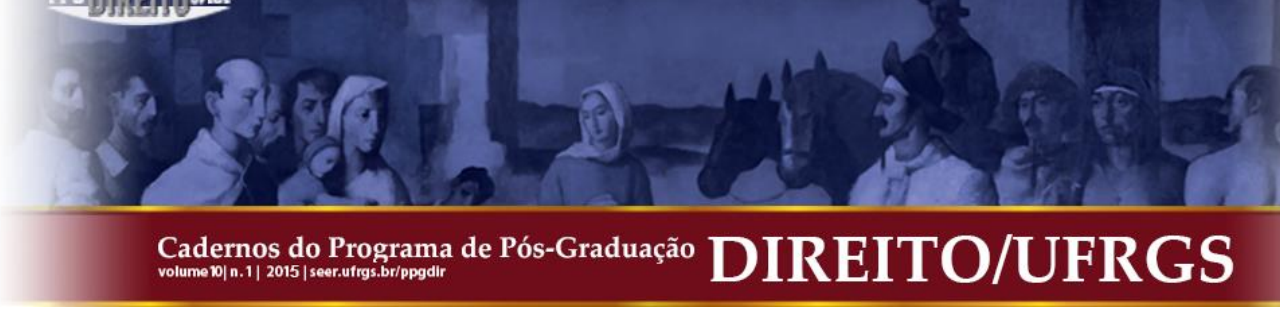

a) forma escrita, ou seja, deve ser tomado mediante termo subscrito pelo agente público competente e pelo infrator ou seu representante legal;

b) consenso entre o órgão público legitimado e o infrator, isto é, a celebração do CAC é uma faculdade, e não uma obrigação;

c) descrição precisa do dano e/ou da conduta que se pretende evitar, cessar ou reparar;

d) obrigações líquidas e certas, com modos e prazos de cumprimento bem definidos (art. 586 do CPC);

e) cominações para o caso de inadimplência das obrigações, ressalvado o disposto no art. 645 do CPC.

Acerca do procedimento, convém esclarecer que o CAC poderá ser firmado tanto no bojo de um processo judicial quanto extraprocessualmente.

Se o CAC foi celebrado processualmente, o referido ajuste de conduta será homologado por sentença, passando a ostentar a natureza de título executivo judicial. Caso o polo ativo processual seja titularizado pelo Ministério Público, não há necessidade de homologação pelo Conselho Superior do Parquet, uma vez que o controle de legalidade já foi realizado pelo Poder Judiciário.

Para os compromissos tomados extraprocessualmente pelo Ministério Público, a celebração do CAC, em regra, levará ao arquivamento do inquérito civil (exceto em caso de ajuste preliminar ou parcial). Ocorrendo a hipótese de arquivamento do inquérito civil, com ou sem o compromisso de ajustamento de conduta, haverá a necessidade de homologação pelo Conselho Superior do Ministério Público ou órgão equivalente (art. $9^{\circ}$, parágrafo $1^{\circ}$ da Lei $7347 / 85)$.

No caso dos compromissos firmados extraprocessualmente por outros legitimados, é de se entender que haverá a ausência de justa causa para o prosseguimento das investigações ou para a propositura de ação de conhecimento, mesmo porque, via de regra, já haverá um título executivo extrajudicial reconhecendo o autor do dano e as obrigações a que este se comprometeu.

Tanto para os compromissos de ajustamento de conduta firmados no bojo de um processo judicial quanto para aqueles firmados extraprocessualmente, haverá a fiscalização do cumprimento do ajuste por parte do órgão público tomador da avença ou de qualquer outro legitimado (a exemplo do Ministério Público) que poderá, ainda, promover a execução do título, se necessário.

\subsection{Efeitos da celebração do compromisso de ajustamento de conduta}




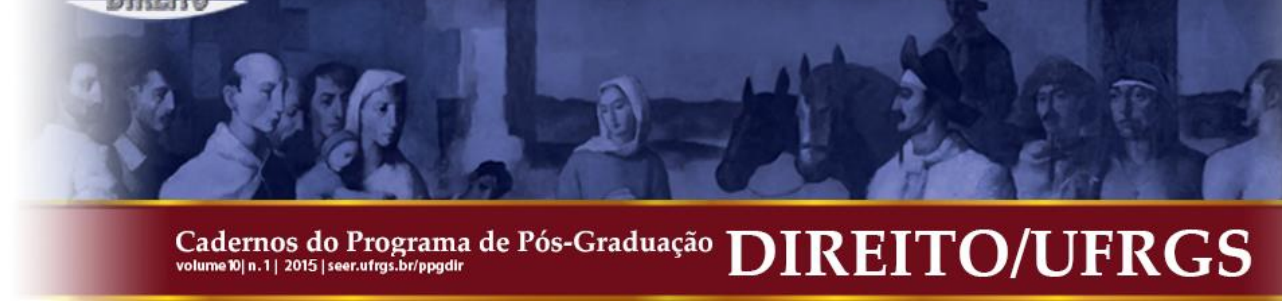

Primeiramente, revela-se importante esclarecer que o CAC já possui eficácia de título executivo extrajudicial a partir do momento em que é firmado o termo entre o órgão público legitimado e o interessado. A Lei n ${ }^{\circ} 7347 / 85$ não impôs nenhuma condição para o CAC passar a produzir efeitos, a exemplo de homologação pelo Conselho Superior do Ministério Público ou arquivamento do inquérito civil. (MAZZILLI, 2005, P. 362).

Ocorre que isto não impede que o próprio compromisso de ajustamento de conduta preveja algumas hipóteses onde seja fixada uma condição ou termo entre o legitimado e o causador do dano para que se iniciem os efeitos do ajuste de conduta.

Desta maneira, via de regra, assim que firmado o CAC, já surgem alguns efeitos principais, tais como (a) obrigar o interessado ao seu cumprimento e (b) a formação do título executivo extrajudicial ou judicial.

Outros efeitos secundários também podem ser mencionados, a exemplo da suspensão do procedimento administrativo no qual foi tomado o CAC ou o seu arquivamento.

A mera concessão de prazo para o cumprimento do ajuste não significa que o CAC ainda não possui eficácia, afinal, o decurso do prazo já é um dos efeitos do compromisso. (RODRIGUES, 2011, p. 185).

Obviamente, o CAC somente tem repercussão na esfera jurídica daquele interessado que o firmou, ou eventualmente de seus sucessores.

Para alguns estudiosos, uma vez firmado o CAC, faltaria aos demais legitimados interesse de agir em propor ação coletiva para se discutir os mesmos fatos objetos da avença anterior, desde que haja suficiência das obrigações e deveres assumidos às exigências legais, afinal, o interesse transindividual já estaria protegido pela formação de um título executivo extrajudicial. É a posição, por exemplo, de Geisa de Assis Rodrigues (2011, p. 187). Isto se deve ao fato de que os legitimados representam a mesma coletividade lesada em seu direito material, não havendo diferença no polo ativo em relação à presença de um ou outro legitimado.

Para outra parcela da doutrina, o CAC é uma garantia mínima de proteção aos interesses transindividuais, de forma que não retira dos demais legitimados a faculdade de elaboração de outro CAC ou de propositura de ação coletiva que pretendam ampliar a proteção dos interesses lesados, fato que será melhor explicitado mais adiante.

Em relação aos indivíduos lesados, o CAC tem o efeito de beneficiá-los, possibilitando, inclusive, a execução individual do ajuste, desde que mediante prévia liquidação, onde o lesado comprove que sofreu um dano decorrente dos mesmos fatos dispostos no termo. 


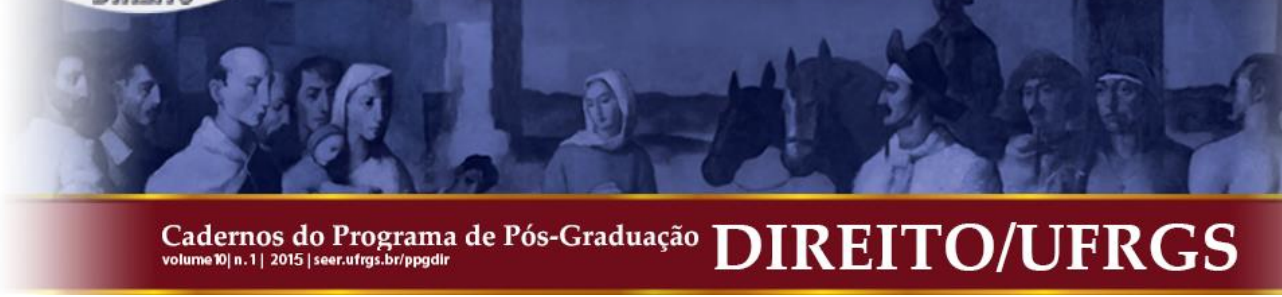

\section{A ADMINISTRAÇÃO INDIRETA DO ESTADO/ DAS EMPRESAS PÚBLICAS E SOCIEDADES DE ECONOMISTA MISTA: SEMELHANÇAS E DIFERENÇAS.}

A atividade administrativa do Estado tanto pode ser prestada diretamente ou por meio de outras pessoas. Neste último caso, o Estado transfere o exercício da atividade administrativa para particulares ou cria pessoas jurídicas para tal mister, em um fenômeno chamado descentralização (MELLO, 2007, p. 145), a exemplo do que ocorre com as chamadas empresas estatais, gênero do qual são espécies as empresas públicas e as sociedades de economia mista.

Desta maneira, na descentralização, o Estado atua indiretamente, por meio de outras pessoas, que possuem personalidade jurídica distinta daquele, ainda quando o Estado seja o criador dos novos entes. Repare que as empresas públicas e as sociedades de economia mista que prestam serviços públicos são exemplos de descentralização administrativa, isto é, são entes distintos do Estado, mas criados por este, para o exercício de parcela da atividade administrativa, consistente justamente na prestação de serviços públicos.

Frise-se que a grande vantagem da descentralização administrativa repousa na especialidade do exercício da atividade, cabendo ainda lembrar que não haverá relação de hierarquia entre o Estado e o outro ente (afinal, as personalidades jurídicas são distintas), mas apenas relação de controle finalístico da atividade.

Já as empresas públicas e as sociedades de economia mista exploradoras de atividade econômica são entidades criadas pelo Estado como forma de intervenção no domínio econômico por participação, onde o Estado assume o controle de parcela dos meios de produção em um determinado setor da atividade econômica, agindo por meio de competição com as empresas privadas que continuam a atuar neste setor. (GRAU, 2012, p. 143).

A atividade econômica, via de regra, é conferida à iniciativa privada, sendo que o Estado somente pode exercê-la quando necessária à segurança nacional ou a relevante interesse coletivo, definidos em lei (art. 173, CF).

Estas são as noções introdutórias que justificam a existência das empresas públicas e das sociedades de economia mista, sejam para a prestação de serviços públicos (art. 175, CF) ou para a exploração de atividade econômica (art. 173, CF). Ambas fazem parte, portanto, da Administração Indireta do Estado.

Cadernos do Programa de Pós-Graduação em Direito PPGDir./UFRGS | Edição Digital | Porto Alegre | Volume X | Número 1 | 2015 | P.211 - 235 


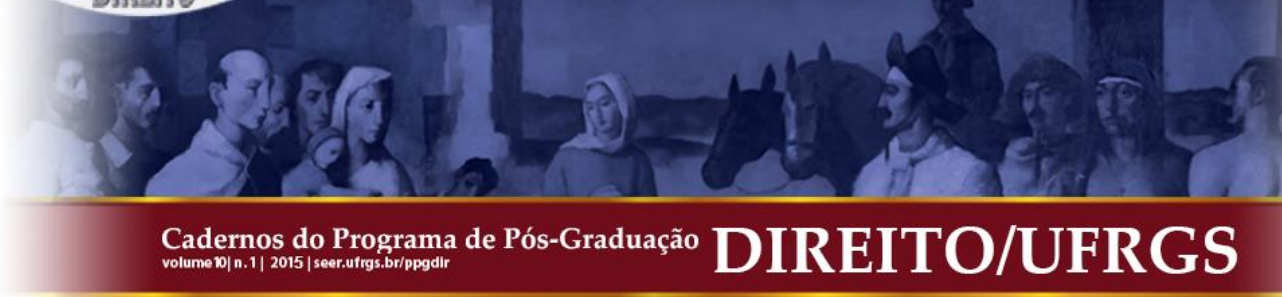

Segundo afirma José dos Santos Carvalho Filho (2007, p. 437),

[...] embora sejam de categorias jurídicas diversas, as empresas públicas e as sociedades de economia mista devem ser estudadas em conjunto, tantos são os pontos comuns que nelas aparecem. Como veremos, essas entidades são dotadas de personalidade jurídica de direito privado e delas se vale o Estado para possibilitar a execução de alguma atividade de seu interesse com maior flexibilidade, sem as travas do emperramento burocrático indissociáveis das pessoas de direito público.

A ideia central de ambas é o Estado intervindo em uma atividade precipuamente afeta aos particulares, uma vez identificado algum interesse público que legitime sua atuação.

Empresas públicas são pessoas jurídicas de direito privado, integrantes da Administração Indireta do Estado, criadas mediante autorização legal, sob qualquer forma jurídica adequada a sua natureza, para que o Governo exerça atividades gerais de caráter econômico ou, em certas situações, execute a prestação de serviços públicos (CARVALHO FILHO, 2007, p. 438). Como exemplos, podem ser citados a Caixa Econômica Federal-CEF e a Empresa Brasileira de Correios e Telégrafos - ECT.

Já sociedades de economia mista são pessoas jurídicas de direito privado, integrantes da Administração Indireta do Estado, criadas por autorização legal, sob a forma de sociedades anônimas, cujo controle acionário pertença ao Poder Público, tendo por objetivo, como regra, a exploração de atividades gerais de caráter econômico e, em algumas ocasiões, a prestação de serviços públicos. (CARVALHO FILHO, 2007, p. 438).

A Constituição Federal faz expressa referência às empresas públicas e às sociedades de economia mista em seu artigo 173, parágrafo $1^{\circ}$. Há outros dispositivos na Carta Magna que igualmente mencionam as referidas entidades: criação e extinção autorizadas por lei (art. 37, XIX e XX) e vedação à acumulação remunerada de cargos e funções (art. 37, XVII), dentre outras menções expressas e implícitas.

No campo infraconstitucional, convém citar o Decreto-Lei no 200/67, o qual traz a base dos conceitos dessas entidades.

Em relação à personalidade jurídica, ambas seguem o regime jurídico de direito privado, obviamente com certas derrogações do direito público.

São três as principais diferenças entre empresas públicas e sociedades de economia mista: (i) forma jurídica, (ii) composição do capital social e (iii) foro processual.

Em relação à forma jurídica, as empresas públicas podem seguir qualquer forma societária. Desta maneira, podem se constituir sob a forma de sociedade limitada, sociedade 


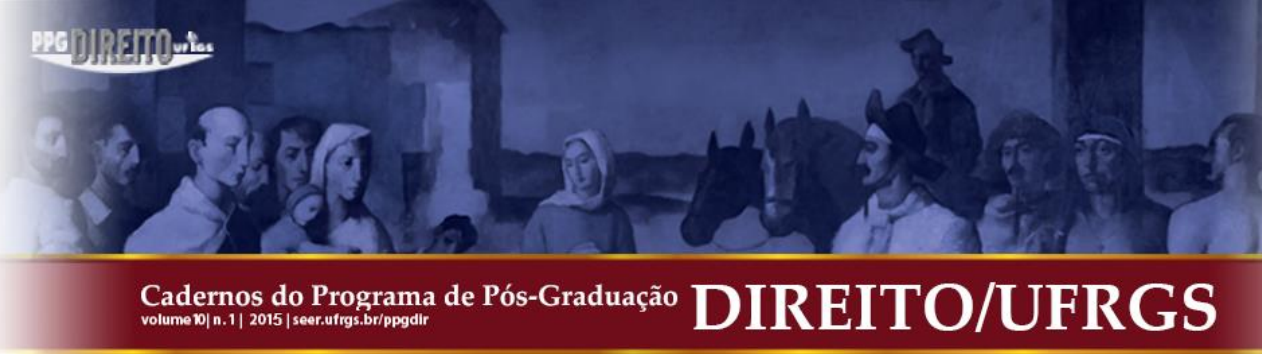

anônima, sociedade civil etc. Já as sociedades de economia mista devem se revestir, obrigatoriamente, sob a forma de sociedade anônima, sendo regida, basicamente, pela Lei das Sociedades Por Ações (Lei Federal no 6404/76).

A composição do capital das empresas públicas deve ser inteiramente público. Vale dizer: não há a possibilidade de participação de capital privado em sua composição; todavia, pode haver a junção de capital público de diferentes entidades públicas para a sua formação. Já nas sociedades de economia mista, como o próprio nome designa, há junção entre o capital público e o privado para a sua formação, sendo que as ações são divididas entre a entidade governamental e a iniciativa privada. O que se exige, neste último caso, é que a maior parte das ações com direito a voto sejam titularizadas pela entidade pública.

As empresas públicas federais que forem autoras, rés, assistentes ou opoentes em processos judiciais, terão as suas causas julgadas pela Justiça Federal, exceto nas ações de falência, acidente de trabalho e as sujeitas à Justiça do Trabalho e à Justiça Eleitoral (art. 109, I, CF). As empresas públicas estaduais, distritais e municipais terão suas causas julgadas perante a Justiça Estadual.

As sociedades de economia mista, por sua vez, não foram contempladas com o foro processual da Justiça Federal, sendo que terão as suas causas julgadas pela Justiça Estadual, sejam tais entidades pertencentes ao âmbito federal, estadual, distrital ou municipal.

\subsection{O fenômeno da autarquização das empresas estatais prestadoras de serviços públicos}

O objetivo do presente trabalho não é discutir à exaustão a polêmica envolvendo o regime jurídico das empresas públicas e das sociedades de economia mista que prestam serviços públicos. Todavia, a compreensão do fenômeno da autarquização das empresas estatais auxiliará na conclusão da ideia central deste trabalho.

É cediço que tais empresas estatais se submetem ao regime jurídico de direito privado.

Contudo, cada vez mais o STF, por meio de sua jurisprudência, vem aproximando o regime jurídico de direito privado das empresas estatais que prestam serviços públicos ao regime jurídico de direito público, como se autarquias fossem, em um fenômeno conhecido como "autarquização das empresas estatais" 6.

\footnotetext{
${ }^{6}$ Este fenômeno jurídico é recente, ainda pouco discutido na doutrina. Porém, certos autores já começam a rechaçálo, sob os seguintes argumentos sintetizados: a - A concessão de privilégios às empresas estatais prestadoras de serviços públicos ocorre por meio jurisprudencial, ao arrepio de previsão expressa na Carta Magna; b - O STF Cadernos do Programa de Pós-Graduação em Direito PPGDir./UFRGS | Edição Digital | Porto Alegre | Volume X | Número 1 | 2015 | P.211-235
} 


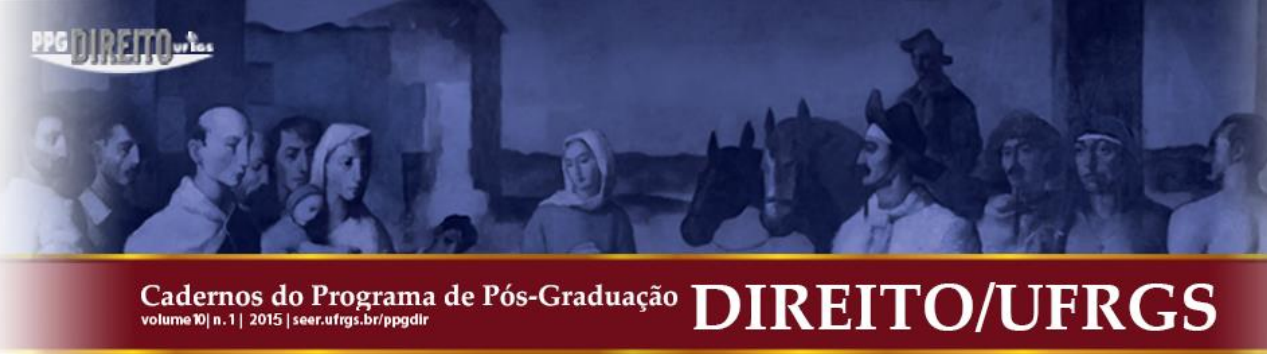

Por meio desse fenômeno, o STF está conferindo prerrogativas antes exclusivas do regime jurídico de direito público a entidades submetidas ao regime jurídico de direito privado, principalmente no tocante à imunidade tributária recíproca e à impenhorabilidade dos seus bens, ensejando a execução dos débitos das empresas estatais prestadoras de serviços públicos pelo regime constitucional do precatório (art. 100, CF).

Com o fenômeno da autarquização das empresas estatais prestadoras de serviços públicos, diminuem-se as diferenças entre os regimes jurídicos de direito público e o de direito privado, transformando tais entidades em verdadeiras autarquias, ao arrepio de sua lei instituidora, o que traz certas consequências jurídicas. Uma dessas consequências, como se verá adiante, será a possibilidade de tais entidades firmarem o CAC para a proteção de interesses transindividuais lesados.

Acerca do tema, não se poderia deixar de mencionar o entendimento do STF na Ação Cível Originária $n^{\circ} 765 / R J$, na qual o Pretório Excelso entendeu que a Empresa Brasileira de Correios e Telégrafos-ECT faz jus à imunidade tributária recíproca, sob o argumento de que, em sendo empresa pública prestadora de serviço público, seu regime jurídico se assemelharia ao da Fazenda Pública (direito público), e não ao das empresas públicas (direito privado). Com isso, na prática, as empresas estatais prestadoras de serviços públicos passaram a gozar dos mesmos privilégios e sujeições da Fazenda Pública, sob o regime jurídico de direito público. Observe-se a ementa:

Tributário. Imunidade recíproca. Art. 150, VI, "a", da Constituição Federal. Extensão.
Empresa pública prestadora de serviço público. Precedentes da Suprema Corte. 1. Já
assentou a Suprema Corte que a norma do art. 150, VI, "a", da Constituição Federal
alcança as empresas públicas prestadoras de serviço público, como é o caso da autora,
que não se confunde com as empresas públicas que exercem atividade econômica em
sentido estrito. Com isso, impõe-se o reconhecimento da imunidade recíproca prevista
na norma supracitada. 2. Ação cível originária julgada procedente. (ACO 765,
Relator(a): Min. MARCO AURÉLIO, Relator(a) p/ Acórdão: Min. MENEZES
DIREITO, Tribunal Pleno, julgado em 13/05/2009, DJe-167 DIVULG 03-09-2009
PUBLIC 04-09-2009 EMENT VOL-02372-01 PP-00001 LEXSTF v. 31, n. 369,
2009, p. 21-45)

ignora por completo os Poderes Legislativo e Executivo, que escolheram outro regime jurídico para aquela empresa estatal prestadora de serviço público; c - o STF acaba por interferir em normas constitucionais de competência tributária, reduzindo o campo legiferante das pessoas políticas que ficam impossibilitadas de cobrar impostos destas empresas estatais; $\mathrm{d}$ - Conforme a jurisprudência do STF, adotou-se um critério subjetivo para se inferir o regime jurídico das empresas estatais prestadoras de serviços públicos, baseado tão-somente no fato destas empresas serem prestadoras de serviços públicos, sem se importar com o serviço público em si, o qual pode ser prestado tanto por empresas estatais, quanto por entidades de direito público ou até mesmo por concessão a particulares; e-Maior dificuldade para o credor particular executar um débito de uma empresa estatal pelo regime do precatório. (PINTO, 2010).

Cadernos do Programa de Pós-Graduação em Direito PPGDir./UFRGS | Edição Digital | Porto Alegre | Volume X | Número 1 | 2015 | P.211-235 


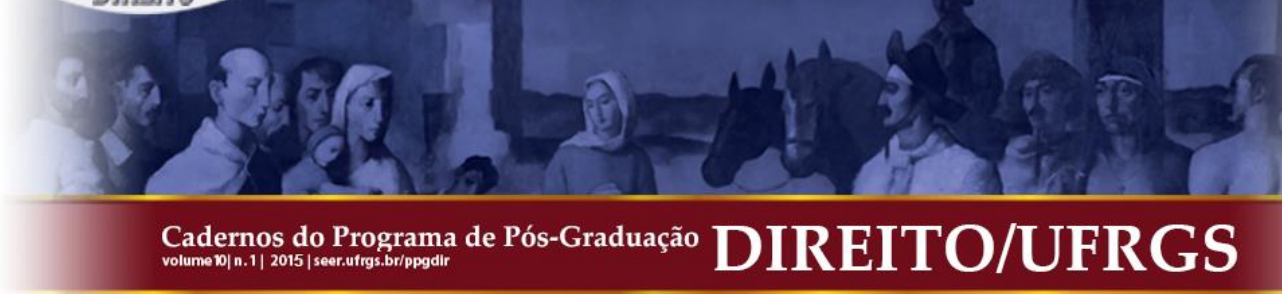

Há outros julgados do STF que corroboram o aludido fenômeno jurídico, a exemplo do $\mathrm{RE} \mathrm{n}^{\circ}$ 610.517/RJ, que trata da concessão de imunidade tributária à Casa da Moeda do Brasil (CMB), empresa pública federal.

Em que pese o fato de tais acórdãos não tratarem especificamente da legitimidade das empresas estatais para firmarem o CAC, eles demonstram que as empresas públicas e as sociedades de economia mista prestadoras de serviços públicos estão, cada vez mais, auferindo benefícios tributários em detrimento de outras pessoas jurídicas de direito privado ${ }^{7}$. Mediante esta constatação, por meio de um raciocínio indutivo, pode-se afirmar que cada vez mais referidas entidades estatais estão se aproximando do regime jurídico público ao qual se submetem as pessoas jurídicas de direito público interno.

Tal lição jurisprudencial é corroborada na doutrina por Roque Antônio Carrazza (2003, p. 655). Observe-se:

Podemos, pois, dizer que, neste caso, as sociedades de economia mista e as empresas públicas, pelas atribuições delegadas do poder público que exercitam, são, tão-só quanto à forma, pessoas de direito privado. Quanto ao fundo são instrumentos do Estado, para a prestação de serviços públicos ou a prática de atos de polícia. Acabam fazendo as vezes das autarquias, embora - damo-nos pressa em proclamar - com elas não se confundem.

Assim, exemplificativamente, as empresas estatais prestadoras de serviços públicos gozam de imunidade tributária recíproca em relação ao patrimônio, renda e serviços vinculados às suas finalidades essenciais ou dela decorrentes; não podem figurar no polo passivo de ações falimentares (art. $2^{\circ}$, I da Lei 11.101/05); somente podem dispensar seus empregados públicos após motivação (STF, RE no 589.998/PI), valendo lembrar que eles são contratados mediante concurso público (art. 37, II, CF); os bens públicos afetados às suas atividades finalísticas são impenhoráveis e insuscetíveis de usucapião (art. 102, Código Civil), chegando-se ao ponto do

\footnotetext{
${ }^{7}$ Ressalte-se que o artigo 150, parágrafo $2^{\circ}$ da Constituição Federal estabelece que a vedação do inciso VI, "a" (leia-se, imunidade tributária recíproca), é extensiva às autarquias e às fundações instituídas e mantidas pelo Poder Público, no que se refere ao patrimônio, à renda e aos serviços, vinculados a suas finalidades essenciais ou às delas decorrentes. Já o parágrafo $3^{\circ}$ do mesmo dispositivo legal preleciona que as vedações do inciso VI, "a", e do parágrafo anterior não se aplicam ao patrimônio, à renda e aos serviços, relacionados com exploração de atividades econômicas regidas pelas normas aplicáveis a empreendimentos privados, ou em que haja contraprestação ou pagamento de preços ou tarifas pelo usuário, nem exonera o promitente comprador da obrigação de pagar imposto relativamente ao bem imóvel. Assim, repare que o parágrafo $2^{\circ}$ afirma que a imunidade tributária recíproca é extensível às autarquias e às fundações públicas, enquanto o parágrafo $3^{\circ}$ estabelece, em linhas gerais, que tal imunidade não pode ser deferida às entidades estatais que explorem atividade econômica, o que levou o STF e boa parcela da doutrina tributarista a concluir que a imunidade recíproca é extensível às empresas públicas e às sociedades de economia mista que prestem serviços públicos, afinal, se a pessoa política concedente do serviço público o prestasse diretamente, ela faria jus a essa imunidade.
} 


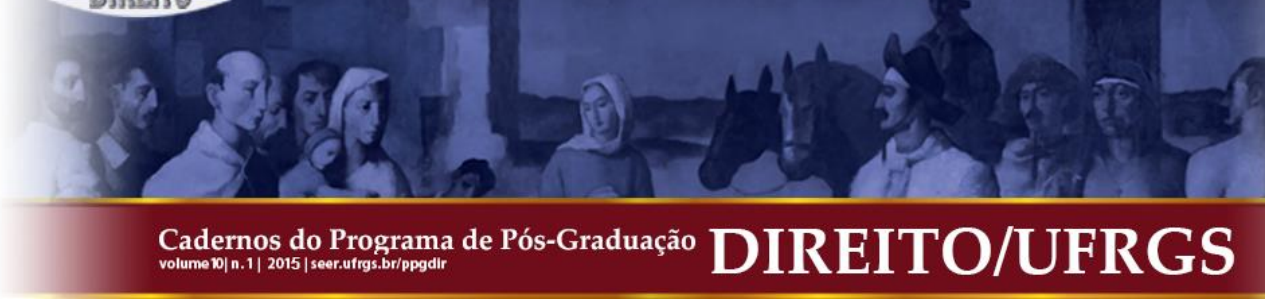

Supremo Tribunal Federal afirmar expressamente que a execução promovida em face da Empresa Brasileira de Correios e Telégrafos-ECT (empresa pública) deve ser feita por meio de precatório $^{8}$. Todas essas características induzem à constatação de que há uma semelhança muito grande entre as empresas estatais prestadoras de serviços públicos e as autarquias, principalmente no tocante à adoção crescente do regime jurídico de direito público por parte das primeiras.

Cabe frisar que a autarquização das empresas estatais prestadoras de serviços públicos não atinge as empresas estatais exploradoras de atividades econômicas, sob pena de se criar indevidos privilégios a estas últimas.

Nesta ocasião, convém lembrar que o Estado somente pode explorar atividade econômica de forma excepcional, por motivos de (i) segurança nacional ou (ii) relevante interesse coletivo (art. 173, parágrafo $1^{\circ}$ da CF). Isto porque, conforme art. 170 da Carta Magna, cabe precipuamente aos particulares o exercício da atividade econômica.

E, nesta exploração da atividade econômica, devem imperar as regras de direito privado (art. 173, parágrafo $1^{\circ}$, inciso II da CF), ou melhor dizendo, as empresas públicas e as sociedades de econômica mista exploradoras de atividade econômica devem se sujeitar ao regime jurídico próprio das empresas privadas quanto a direitos e obrigações civis, comerciais, trabalhistas e tributárias.

A razão de ser dessa obrigação é um tanto quanto evidente: se as empresas públicas e sociedades de economia mista exploradoras de atividade econômica pudessem gozar de privilégios não extensíveis aos particulares, haveria nítido desequilíbrio no setor econômico de sua atuação.

Isso significa dizer, por exemplo, que tais entidades seguem o direito privado em relação às ações por responsabilidade civil, não possuem prerrogativas processuais, seus empregados gozam dos mesmos direitos trabalhistas dos demais empregados de outras sociedades empresárias privadas, regime tributário idêntico aos particulares etc.

\subsection{As empresas públicas e as sociedades de economia mista como legitimadas para a celebração de compromisso de ajustamento de conduta}

Pelo artigo $5^{\circ}$ da Lei Federal no 7347/85 (Lei de Ação Civil Pública - LACP), são legitimados para a propositura da ação civil pública o Ministério Público, a Defensoria Pública,

\footnotetext{
${ }^{8}$ Vide RE no 336.685/MG, Rel. Min. MOREIRA ALVES, j. 12.03.2002).
}

Cadernos do Programa de Pós-Graduação em Direito PPGDir./UFRGS | Edição Digital | Porto Alegre | Volume X | Número 1 | 2015 | P.211 - 235 


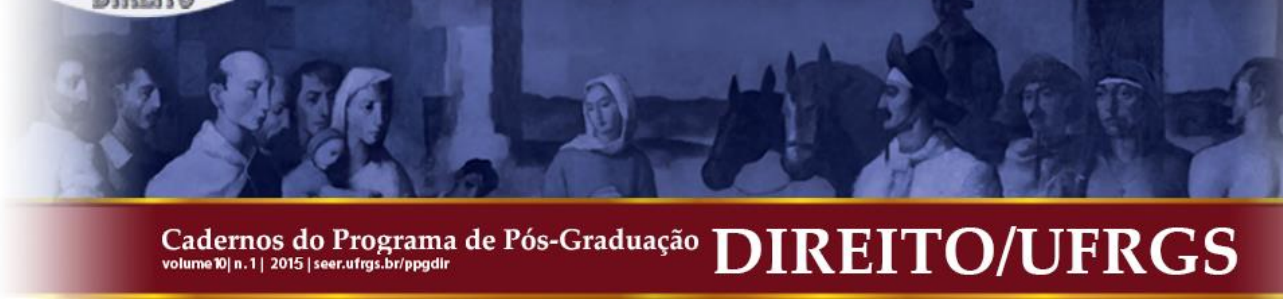

os entes federados, as autarquias, empresas públicas, fundações ou sociedades de economia mista e as associações que, concomitantemente, estejam constituídas há pelo menos um ano e incluam entre as suas finalidades a proteção aos interesses indicados no art. $5^{\circ}$, inciso $\mathrm{V}$, alínea b, do mencionado diploma legal.

Já o artigo $5^{\circ}$, parágrafo $6^{\circ}$ da LACP, estabelece que podem firmar o CAC os "órgãos públicos" legitimados à propositura da ação civil pública.

Em princípio, já se denota que a expressão “órgãos públicos” não foi utilizada em seu sentido técnico, isto é, como centro de atribuições administrativas desprovido de personalidade jurídica. Causa a impressão de que a lei quis se referir às pessoas jurídicas de direito público como legitimadas para firmar o CAC, deixando expressamente de fora as associações, os sindicatos e as fundações privadas.

A expressão "órgãos públicos" comporta controvérsia bem sintetizada por Geisa de Assis Rodrigues (2011, p. 141):

[...] cumpre verificar quais entes a norma abrange na locução ‘órgãos públicos'. Esse vocábulo tem um conceito técnico específico de direito administrativo, significando um centro de atribuições administrativas, sem personalidade jurídica. No entanto, reputamos, na companhia de toda a doutrina, que a lei adotou um significado mais amplo de órgãos públicos para dar uma ênfase às atribuições públicas de quem poderá promover a tutela extrajudicial desses direitos.

Observa-se, pois, que a legitimidade das empresas públicas e das sociedades de economia mista para celebrarem compromisso de ajustamento de conduta não é tão clara assim. A lei não dispõe, expressamente, se tais entidades são ou não legitimadas para celebrarem o CAC.

As empresas públicas e as sociedades de economia mista não são pessoas jurídicas de direito público interno nem órgãos da Administração Direta do Estado. Em verdade, ambas possuem personalidade jurídica de direito privado, ainda que instituídas ou mantidas pelo Poder Público.

Como se viu, há duas espécies de empresas públicas e sociedades de economia mista: as exploradoras de atividade econômica e as prestadoras de serviços públicos.

A Constituição Federal determina que as empresas públicas e as sociedades de economia mista, sejam exploradoras de atividade econômica ou prestadores de serviços públicos, adotem o regime jurídico de direito privado, a fim de evitar a concessão de qualquer privilégio às empresas estatais que não sejam extensíveis às demais empresas do setor privado. 


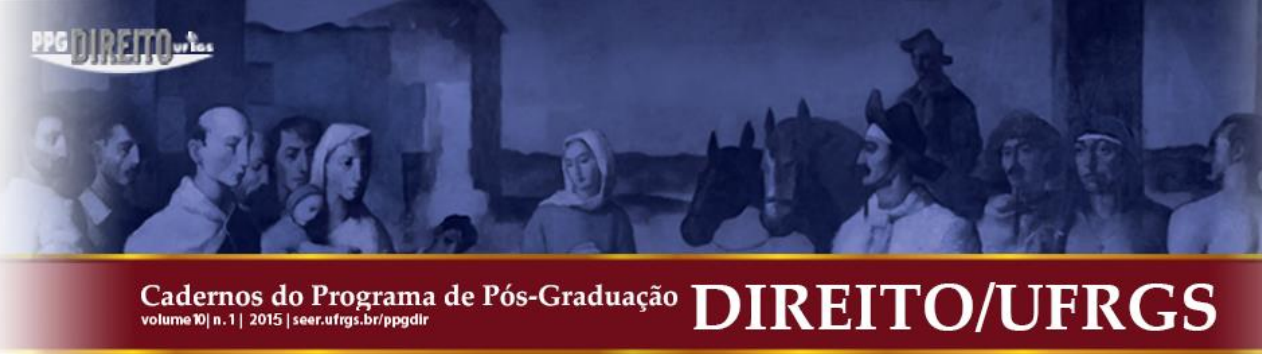

Destarte, para alguns doutrinadores, as empresas públicas e as sociedades de economia mista, sejam exploradoras de atividade econômica, sejam prestadores de serviços públicos, não teriam legitimidade para celebrar CAC, justamente por adotarem o regime jurídico de direito privado, sendo que a LACP (Lei Federal $n^{\circ}$ 7347/85) somente confere legitimidade para tal mister às pessoas jurídicas de direito público interno e aos "órgãos públicos”. Vale dizer: tendo em vista que as empresas públicas e as sociedades de economia mista não são pessoas jurídicas de direito público nem órgão público, simplesmente a LACP não as teria contemplado como legitimadas para o CAC. Esta é a posição de José dos Santos Carvalho Filho (1995, p. 136), in verbis:

Em consequência, têm permissão para tomar o compromisso de ajustamento de
conduta a União, os Estados, o Distrito Federal, os Municípios, as autarquias e
fundações de direito público, e o Ministério Público. Não a terão, todavia, as empresas
públicas, as sociedades de economia mista e as fundações públicas de direito privado
(porque, embora da Administração Pública, são dotadas de personalidade de direito
privado), bem como as associações que preencham os requisitos do art. $5^{\circ}$, I e II.
Nenhuma destas últimas pode qualificar-se como órgão público, por mais ampla que
seja a interpretação do texto legal.

Por sua vez, Edis Milaré (1995, p. 397) aduz que, quando a LACP confere legitimidade aos “órgãos públicos", ela não utiliza o vocábulo "público" em sua expressão técnica, mas apenas como forma de se afastar da legitimidade para a celebração do CAC as associações, que não guardariam qualquer vínculo com o Poder Público. Já as entidades paraestatais, em que pese possuírem personalidade jurídica de direito privado, teriam, em última instância, uma finalidade pública.

Todavia, para outros doutrinadores, a exemplo de Hugo Nigro Mazzilli (2005, p. 358), há a necessidade de se proceder a uma cisão entre as empresas públicas e as sociedades de economia mista prestadoras de serviços públicos daquelas entidades exploradoras de atividade econômica.

Em outras palavras, quando as empresas estatais prestam serviço público, elas estão administrando um interesse público, de modo que se revela aceitável que possam celebrar o CAC, justamente como forma de se preservar o interesse social, entendimento este corroborado pela crescente autarquização das empresas estatais prestadoras de serviços públicos, conforme exposto acima.

Todavia, quando os entes estatais exploram atividades econômicas, não se pode admitir que celebrem o CAC, uma vez que não podem ser dotados de "privilégios" não extensíveis às 


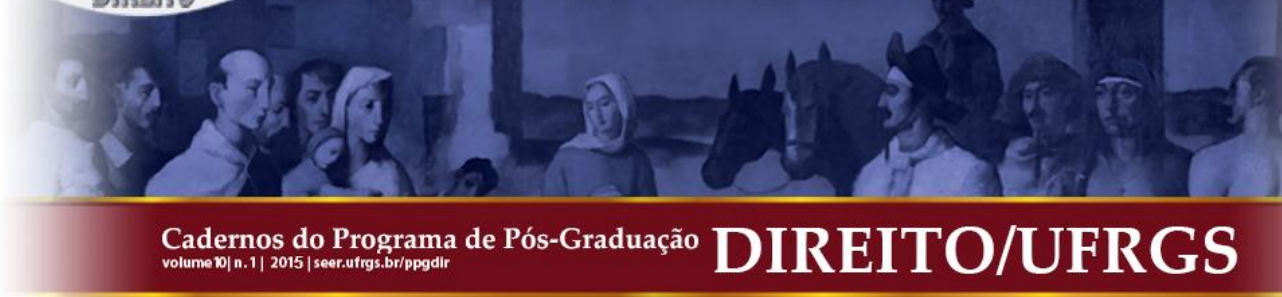

demais empresas do setor privado. Haveria nítida desigualdade, com ofensa ao Princípio da Isonomia (art. $5^{\circ}$, caput, $\mathrm{CF}$ ), caso as empresas estatais pudessem firmar o CAC em detrimento das demais empresas privadas existentes naquele setor econômico. Haveria, assim, um "superpoder" conferido às empresas estatais, o que inegavelmente afrontaria a Constituição Federal (art. $5^{\circ}$, caput e art. $173 \mathrm{da} \mathrm{CF}$ ), sob duas vertentes: (i) as empresas estatais teriam uma prerrogativa não outorgada às demais empresas privadas exploradoras de atividade econômica, o que lhes conferiria maior relevância no mercado econômico e (ii) as empresas estatais, que não deixam de ser pessoas jurídicas de direito privado, teriam o "poder estatal" de firmarem o CAC com os supostos causadores do dano, em espécie de verdadeira "delegação do poder de polícia”, já rechaçada pelo $\mathrm{STF}^{9}$. Vale lembrar que a interpretação teleológica da Carta Magna dá a entender que não haverá privilégios conferidos às empresas estatais que não sejam extensíveis aos demais particulares.

Para Geisa de Assis Rodrigues (2011, p. 181),

[...] a natureza privada do órgão, ao nosso sentir, tanto de associações, como de sociedades de economia mista e de empresas públicas exploradoras do domínio público, organizações sociais, invalida a existência do ajuste como tal, podendo constituir um pacto de intenções ou um acordo de cavalheiros, mas não um ajustamento de conduta.

Poder-se-ia argumentar que as empresas estatais, ainda que exploradoras de atividade econômica, também perseguem o interesse público, uma vez que só podem explorar o mercado econômico por razões de segurança nacional e relevante interesse coletivo (art. 173, parágrafo $\left.1^{\mathrm{o}} \mathrm{da} \mathrm{CF}\right)$.

Todavia, constata-se que, quando as empresas estatais exploram atividade econômica, a perseguição do interesse público acaba sendo relegada a um plano secundário. Em linguagem mais simples, o objetivo lucrativo ganha inegável contorno de prioridade frente ao interesse público. Melhor dizendo: as razões de segurança nacional e relevante interesse coletivo (art. 173, parágrafo $1^{\circ}$ da $\mathrm{CF}$ ) serviram de base para justificar a criação da empresa estatal exploradora da atividade econômica, sendo que, a partir de sua criação, a empresa estatal irá, efetivamente, como o próprio nome designa, explorar a atividade econômica em determinado setor do mercado de consumo, como se particular fosse.

\footnotetext{
${ }^{9}$ Vide ADI n 1717, Rel. Min. Sydney Sanches, j. 07.11.2002.
} 


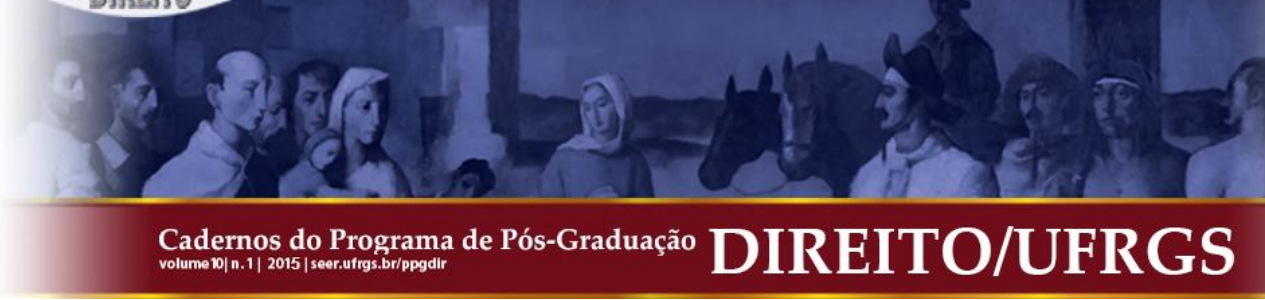

Em contrapartida, o escopo principal das empresas estatais que prestam serviço público é justamente atender à finalidade pública. Nas palavras de Roque Antonio Carrazza (2003, p. 652), “a circunstância de serem revestidas da natureza de empresa pública ou de sociedade de economia mista não lhes retira a condição de pessoas administrativas, que agem em nome do Estado, para a consecução do bem comum."

Além disto, um argumento de ordem prática também reforça a tese da impossibilidade das empresas estatais exploradoras de atividade econômica firmarem o CAC: como elas atuam em determinado seguimento econômico em igualdade de condições com os particulares e tendo em vista que objetivam precipuamente a obtenção de lucro, fica fácil perceber que, se tais empresas estatais pudessem celebrar o CAC, poderia haver certo favorecimento ao interessado no CAC (leia-se, ao causador do dano) a depender do interesse econômico que estivesse por trás do objeto da avença.

Obviamente, os legitimados pela Lei da Ação Civil Pública e pelo Código de Defesa do Consumidor para firmarem o CAC também podem, ao arrepio dos requisitos legais, favorecerem indevidamente determinados particulares quando da assinatura da avença. Todavia, há normas de direito público (principalmente de direito processual e administrativo) que buscam minimizar tal risco ou punir o responsável pelo ato ilícito caso este venha a ocorrer. Assim, o regime jurídico de direito público é extremamente mais rígido e menos condescendente com eventual ato ilícito praticado quando da celebração do CAC. Ademais, em regra, tais entes legitimados buscam precipuamente a satisfação do interesse público, isto é, não há objetivo lucrativo na atividade estatal que exercem. Eventual desvio desta finalidade pode e deve ser punido pelo regime jurídico de direito público.

Destarte, a possibilidade das empresas públicas e das sociedades de economia mista prestadoras de serviços públicos firmarem CAC também é defendida por Geisa de Assis Rodrigues (2011, p. 142). Observe-se:

\footnotetext{
Nesse ponto, alteramos nosso entendimento anterior que nunca admitia a legitimidade das sociedades de economia mista e das empresas públicas para tomarem o compromisso de ajustamento de conduta. $\mathrm{Na}$ verdade, também para efeito de celebração de ajustamento de conduta, vale a distinção entre as sociedades de economia mista e as empresas públicas prestadoras de serviços públicos e as exploradoras de atividade econômica. As prestadoras de serviços podem ter, entre suas atividades, a celebração de ajustamento de conduta, sendo que as exploradoras do domínio econômico não poderiam ter essa atribuição.
} 


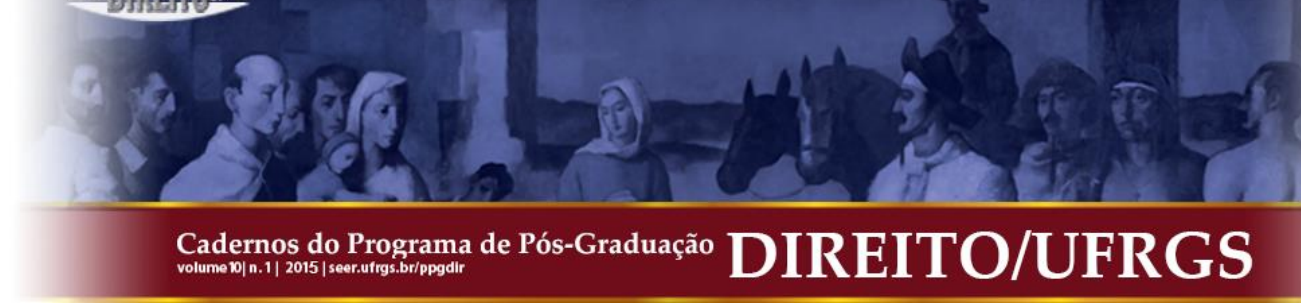

Essa tese doutrinária que confere legitimidade para firmar o CAC às empresas estatais que prestam serviço público, ao mesmo tempo em que a negam para as empresa estatais que exploram atividade econômica parece ser corroborada pelos recentes entendimentos jurisprudenciais que (praticamente) elevam as empresas estatais prestadoras de serviço público ao regime jurídico de direito público. Vale dizer: há uma tendência cada vez maior em se conferir as mesmas prerrogativas de Poder Público às empresas estatais prestadoras de serviço público. A grosso modo, não seria de todo descabido afirmar que as empresas estatais prestadoras de serviços públicos estão cada vez mais se assemelhando às autarquias e fundações públicas (obviamente respeitadas certas especificidades) ${ }^{10}$. As recentes decisões do STF, já retratadas alhures, confirmam esta verificação de tendência.

\section{CONCLUSÃO}

A Lei da Ação Civil Pública (Lei Federal no 7347/85) não foi muito clara ao delimitar, em seu artigo $5^{\circ}$, parágrafo $6^{\circ}$, que “os órgãos públicos legitimados [à ação civil pública] poderão tomar dos interessados compromisso de ajustamento de sua conduta às exigências legais, mediante cominações, que terá eficácia de título executivo extrajudicial”.

Em primeiro lugar, porque a expressão “órgãos públicos” comporta um sentido técnico no Direito Administrativo, o qual não se confunde com o sentido pretendido pelo legislador da Lei 7347/85, que, aparentemente, pretendeu dizer "pessoas jurídicas de direito público".

Em segundo lugar, ainda que o legislador tivesse utilizado a expressão "pessoas jurídicas de direito público" para se referir aos legitimados para firmarem CAC, mesmo assim haveria controvérsia sobre a inclusão ou não das empresas públicas e das sociedades de economia mista nesta legitimidade.

Isto porque, apesar de serem formalmente "pessoas jurídicas de direito privado", por força do artigo 173, inciso II da Constituição Federal, tais entidades estatais se submetem ao regime jurídico de direito privado, com algumas derrogações do direito público, ou seja, não adotam um regime privado de forma absoluta, mas sim um regime jurídico híbrido.

Ademais, em se tratando de empresas públicas e sociedades de economia mista que prestem serviços públicos, é acentuada a incidência do regime jurídico de direito público sobre as suas atividades.

${ }^{10}$ É o fenômeno da autarquização das empresas estatais, promovido pelo STF, já retratado neste trabalho. Cadernos do Programa de Pós-Graduação em Direito PPGDir./UFRGS | Edição Digital | Porto Alegre | Volume X | Número 1 | 2015 | P.211-235 


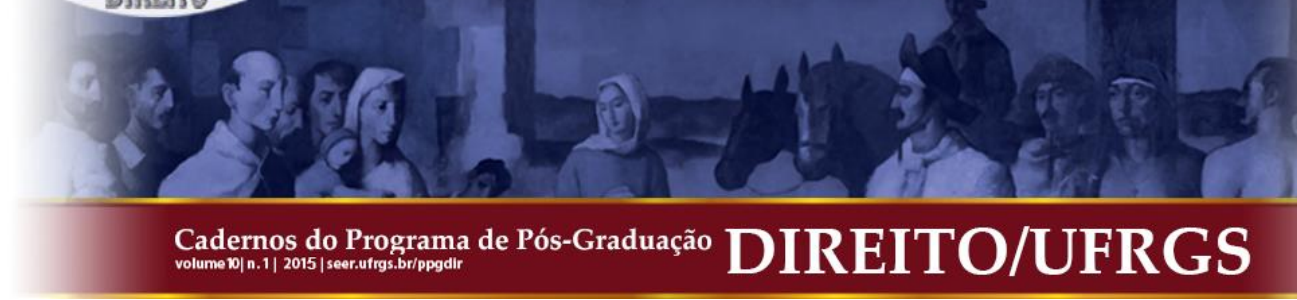

Como visto, o Supremo Tribunal Federal vem proferindo constantes decisões no sentido de conferir cada vez mais às empresas públicas e sociedades de economia mista prestadoras de serviços públicos prerrogativas antes deferidas apenas às pessoas jurídicas de direito público, a exemplo da imunidade tributária recíproca (art. 150, VI, a, da CF).

Tais fatos induzem ao raciocínio de que as empresas públicas e as sociedades de economia mista prestadoras de serviços públicos possam ser consideradas, ao menos no mundo fenomênico, como verdadeiras pessoas jurídicas de direito público, ostentando a legitimidade para celebrarem compromisso de ajustamento de conduta na sua área de atuação.

Trata-se, em verdade, de uma interpretação extensiva ${ }^{11}$ do artigo $5^{\circ}$, parágrafo $6^{\circ}$ da Lei $n^{\circ} 7347 / 85$, no tocante à expressão “órgãos públicos”, ou seja, considera-se que a lei disse menos que a vontade do legislador. Presume-se que era vontade do legislador ter incluído as empresas públicas e as sociedades de economia mista prestadoras de serviços públicos como legitimadas para a celebração de compromisso de ajustamento de conduta.

As empresas públicas e sociedades de economia mista exploradoras de atividade econômica não ostentam tal legitimidade, uma vez que seu objetivo primordial é o lucro, o que poderia gerar entraves ou odiosos privilégios se lhes fossem conferida a mesma benesse.

Este entendimento, inclusive, vai ao encontro da necessidade de ampliação dos legitimados para a tutela dos interesses transindividuais, isto é, deve haver, sempre que possível, a ampliação dos legitimados para o ingresso de ações e para a celebração do CAC, o que, obviamente, confere maior proteção aos direitos coletivos lato sensu, observando-se a indispensável pertinência temática. Desta maneira, o Princípio do Amplo Acesso à Justiça (art. $5^{\circ}, \mathrm{XXXV}$, da CF) também passa a ser maximizado, e não amesquinhado.

Por todas essas razões, é de se entender que as empresas públicas e as sociedades de economia mista prestadoras de serviços públicos possuem legitimidade para celebrarem CAC em suas respectivas áreas de atuação, respeitando-se a finalidade disposta na lei de sua criação.

\section{REFERÊNCIAS}

\footnotetext{
${ }^{11}$ A interpretação é extensiva quando o intérprete considera a lei aplicável a casos que não estão abrangidos pelo seu teor literal. Distingue-se interpretação extensiva da analogia, no sentido de que a primeira é extensiva do significado textual da norma e a última é extensiva da intenção do legislador, isto é, da própria disposição. (CINTRA, 1998, p. 103).
} 


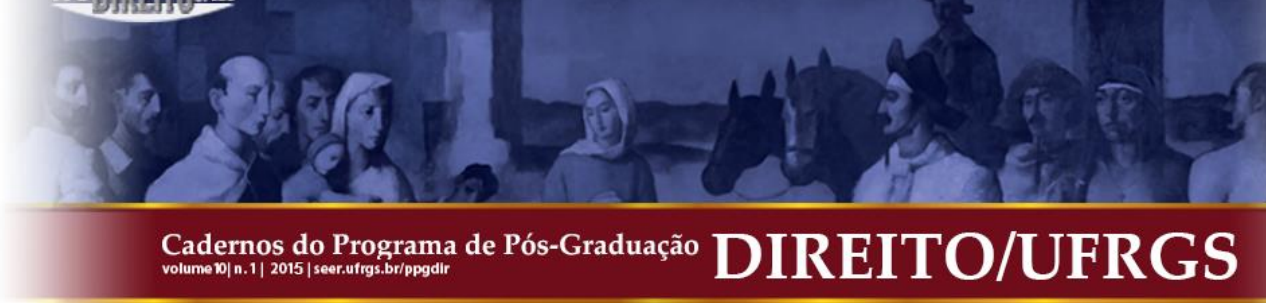

BENJAMIN, Antônio Herman V.; MARQUES, Cláudia Lima; BESSA, Leonardo Roscoe. Manual de Direito do Consumidor. $2^{\circ}$ edição. São Paulo:Revista dos Tribunais, 2009.

CARRAZZA, Roque Antonio. Curso de Direito Constitucional Tributário. $19^{\mathrm{a}}$ edição. São Paulo: Editora Malheiros, 2003.

CARVALHO FILHO, José dos Santos. Manual de Direito Administrativo. $18^{\mathrm{a}}$ edição. Rio de Janeiro: Lumen Juris. 2007. . Ação Civil Pública: comentários por artigo. Rio de Janeiro: Freitas Bastos, 1995.

CINTRA, Antonio Carlos de Araújo; GRINOVER, Ada Pellegrini; DINAMARCO, Cândido Rangel. Teoria Geral do Processo. 14a edição. São Paulo: Malheiros Editores, 1998.

GARCIA, Emerson; ALVES, Rogério Pacheco. Improbidade Administrativa. $4^{\mathrm{a}}$ edição. Rio de Janeiro: Lumen Juris, 2008.

GRAU, Eros Roberto. A ordem econômica na Constituição de 1988. 15a edição. São Paulo: Editora Malheiros, 2012.

MAZZILLI, Hugo Nigro. A defesa dos interesses difusos em juízo. $18^{a}$ edição. São Paulo: Saraiva, 2005.

MELLO, Celso Antônio Bandeira de. Curso de Direito Administrativo. 22 edição. São Paulo: Editora Malheiros, 2007.

MILARÉ, Edis. Ação Civil Pública - Lei n. 7.347/85 - Reminiscências e reflexões após dez anos de aplicações. São Paulo: Revista dos Tribunais, 1995.

MOREIRA, José Carlos Barbosa Moreira. Ações Coletivas na Constituição Federal de 1988. Revista de Processo, n. 61. São Paulo: Revista dos Tribunais, 1992.

NUNES JÚNIOR, Vidal Serrano (Org.). Manual de Direitos Difusos. São Paulo: Verbatim, 2012. 
PINTO, Henrique Motta. A autarquização das empresas estatais na jurisprudência do Supremo Tribunal Federal: um obstáculo para as reformas na administração pública. Cadernos Gestão Pública e Cidadania, São Paulo, vol. 15, num. 57, 2010.

RODRIGUES, Geisa de Assis. Ação Civil Pública e Termo de Ajustamento de Conduta. Rio de Janeiro: Forense, 2011.

Submissão: $13 / 03 / 2015$

Aceito para Publicação: 16/06/2015 


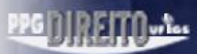

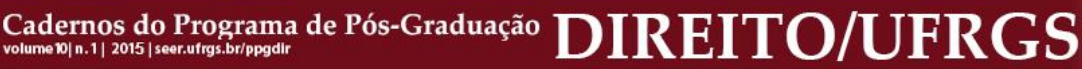

235 